\title{
AGAINST (DESIGN) RESEARCH
}

\author{
Ferdinand Indrajaya \\ Jurusan Desain Komunikasi Visual, School of Design, BINUS University \\ Jln. K.H. Syahdan No. 9, Palmerah, Jakarta 11480, Indonesia \\ ferdinand_indrajaya@yahoo.ca
}

\begin{abstract}
The content of this article is an attempt to show that the word research in traditional sense (within the Cartesian scheme) is hostile to design activity. It will reduce the process of design into a merely fix mechanical process, burying the aspect of imagination, creativity, and more importantly proposing in it that is a crucial aspect to design. This imposition might indiscipline (in a formal academic sense) design as a discipline in human sciences. In order to achieve this, the article is divided in three sections. The first section will discuss what scientific research is and what traditionally presupposed in it: objective, neutral, and a-historical; simply the disinterestedness of research. As for the second, epistemological concerns on traditional scientific research from two philosophers of science will be discussed: Thomas S. Kuhn and Paul K. Feyerabend. As for the third, the closing section, an attempt to delineate design and what designers do in comparison to scientists' will be discussed. It is how design and designers are different in their manners with traditional science and scientist.
\end{abstract}

Keywords: disinterested, design, proposal, research, science

\begin{abstract}
ABSTRAK
Artikel ini merupakan sebuah kajian yang menunjukkan makna kata penelitian secara tradisional (dalam skema Cartesian) yang berhubungan dengan aktivitas desain. Makna tersebut akan mengurangi proses desain menjadi proses fiksasi mekanik; menggugurkan aspek imajinasi, kreativitas; dan yang terpenting, mengusung penelitian sebagai aspek krusial dalam desain. Pemaknaan ini bisa menjadi ketidakdisiplinan (dalam makna akademis resmi) desain sebagai disiplin humaniora. Karenanya, artikel dibagi menjadi tiga sesi. Pertama membahas makna penelitian ilmiah dan apa saja yang termasuk di dalamnya secara tradisional (objektif, netral dan sesuai sejarah; ketidakadilan dalam penelitian. Kedua, pertimbangan epistemologi dalam penelitian ilmiah tradisional dari dua filsuf ilmiah: Thomas S. Kuhn dan Paul K. Feyerabend. Ketiga, membahas hubungan desain dan desainer dalam perbandingan dengan ilmuwan; bagaimana desain dan desainer berbeda dari sikap mereka terhadap ilmu dan ilmuwan tradisional.
\end{abstract}

Kata kunci: disinterested, design, proposal, research, science 


\section{INTRODUCTION}

\section{On the Disinterestedness of Research}

This first section of the article here will briefly discuss the presupposition applied in research activity, specifically what has become a tradition in scientific research. From the word itself, research, as an English word, means a process of repeated searching for patterns that are manifest in available data and facts (Krippendorff, 2007) as truth. In German languages, Forschung, signifies a rigorous activity of inquiry for truth that also requires repeated searching. Traditionally, science aims to validate propositions that state facts and departs from facts. Research is the activity that accommodates in accomplishing this aim. What kind of facts will be a natural one and for the next, the words traditional science or traditional scientific research will refer to approaches (laws or theories) applied in natural science. Nature is positioned as an object of research for scientists from which laws or theory are extracted in order to understand reality better.

Placing nature as an object to be uncovered by this research activity is not an easy task because nature doesn't talk, but human does. So, since nature doesn't talk to reveal itself, scientists are the ones who do most of the talking among themselves, but talking is not considered as scientific activity. In order for the researching activity to be scientific, the scientists as an observer of nature try their best to approach nature objectively. Through excluding observer's subjectivities from propositions about reality (the world), a key feature that signifies the word 'scientific' in 'scientific research' is thus validated. With this kind objective approach to nature, science tends to also apply and generalize this approach to not only natural science, but also human sciences. The more objective one's approach while doing research, the more scientific it is. This objectivity in science is presupposed by a certain level of disinterestedness. The more disinterested, the more valid and scientific a research is. Nature (and also human) is considered as a bunch or a collection of facts ready to be observed and exhausted. Claiming to observe objectively, collected and found data are considered as neutral and fixed as it is. Data is representation of nature as the way it is, (claimed to be) detached from observer's context and interest.

This view that science and scientist should be disinterested towards nature or object that is researched or observed has been quite of an enchantment since the dawn of modernity. It was Réne Descartes (1596-1650), a French philosopher, whose philosophical view provided a modern ground for traditional science, especially his human philosophy. His anthropological view on human is understood as dualism (Hardiman, 2007). It's a concept or ideology that views human mind / soul and human body as two separate entities. This kind of dualistic view on human and the world was actually set earlier by Plato (427-347 BC), a Greek philosopher in antiquity era. The dualism in Cartesian view on human treats mind or soul as a controller of the body; body is considered as a machine for the mind or soul. The word machine signifies that the body is capable to work automatically and mechanically apart from mind or soul. The task of mind or soul is to control this machine to work accordingly. Human body is seen as a mechanical object for the mind. Mind or soul is interpreted and understood as subject and the body as an object for the mind or soul. To explain how these two separated entities are related one to another, Descartes pointed at a small gland inside the brain (glandula pinealis) to bridge these two separated entities. This pineal gland, according to Descartes, made the relation between mind or soul and body possible. This makes possible for one to smile physically while one's mind or soul at the same time is in a troublesome or anxious situation.

Then how is this Cartesian dualism view on human grounds and affects the traditional view on science? The most influential and enchanting dogma to science is his subject-object scheme as an implication from his distinction of mind or soul and body. As mentioned earlier, the mind or soul stands as the controlling subject while the body as a mechanistic machine controlled by the subject. We can simply replace the word 'subject' to the word 'scientist' and the word object to the word 
nature or world. Scientist, disinterestedly is detached from the nature that is observed as well as subject (mind or soul) is detached or separated entity from it's object (the body). The body is necessarily an object, it is not viewed as part of the subject; the body is not a milieu to conscious subject, it is different. Again, the more they are detached one from another, the more disinterested and objective the research is; it is considered as a valid inquiry to truth.

\section{DISCUSSION}

\section{Epistemological Concerns on Scientific Research}

The implication of this Cartesian subject-object scheme is that objective interpretation is an absolute necessity for a research to be scientifically valid. This mechanization of the world view through the subject-object scheme has been infesting the mind of the scientist traditionally. Form this objective interpretation about the world, it emerges intellectualism and empiricism (Hardiman, 2007). The first, supposes that the world or reality is embedded in the thinking subject thus reality or the world is adequate to what is constructed inside our head. The later, empiricism, on the other hand, states that human consciousness is a reflection from the objective world. As long as it is reflected on our consciousness, it is validated to be objective. Even these two isms sounds contradictive one to another, there's one thing that are identical one from another. They both claim the capability of science to fully understand reality to its very core totally. This claim leaves no room for context, crisis, and creativity from scientist as a historical human individual. Nature and the world are viewed, exhausted objectively and a-historically. Scientist is seen as mechanized disinterested subject like a merely quantity of data or natural fact.

Responding to this kind of tradition in science, here we will discuss two views from two different philosopher of science. The first to be discussed will be an American science historian and science philosopher, Thomas S. Kuhn (1970) and secondly, Paul K. Feyerabend (1993), an Austrian science philosopher who is considered as the most controversial and adventurous figure in the postKuhn era (Godfrey-Smith, 2003). These two science thinkers raised few epistemological issues regarding approach in traditional scientific research. Form Kuhn, he emphasized the importance of context through his concept of paradigm and crisis in science, while Feyerabend (1993) emphasized the importance of freedom to think divergently in science. Kuhn's view is more ontological (the being of science), while Feyerabend is more existential (viewing scientist as an free individual subject whose decisions define his existence).

In order to describe the importance of Kuhn's view is to say that he shattered the traditional myths about traditional science, especially what has been embedded in empiricist tradition (GodfreySmith, 2003). Kuhn showed that the work of science has actually little to do with traditional views on rationality and knowledge. In showing this, here in this article, we will focus on two important terms from Kuhn, first, is paradigm and crisis as the second one. The term paradigm in Kuhn sense means a whole way of doing science; it is a package of claims about the world, methods for gathering and analyzing data, and also habits of scientific thought and action (Godfrey-Smith, 2003). This understanding of paradigm is considered as a broad sense of paradigm. What paradigm in a broad sense tries to show is that the whole way of doing science is always within certain particular context and always historical within a particular age of time. Science and scientist are never a-contextual and the research method is never a-historical. Therefore the presupposition that merely emphasizes the disinterested aspect of science is shattered.

What makes this paradigm in a broad sense possible is the paradigm in a narrower sense (Godfrey-Smith, 2003). What is this paradigm in the narrow sense? According to Kuhn, one key part of the paradigm in a broad sense is a specific achievement or an exemplar proposed and signified by a scientist. This specific achievement or exemplar later as time flows will inspire to other scientists, this 
will suggest a different way to investigate the world; this is understood as paradigm in a narrow sense. The broad sense of paradigm is included within the narrow sense of paradigm. The specific achievement proposes a different way to investigate the world and this different way of investigating will become a new whole way of doing science. So, the whole way of doing science is intrigued by an emerging specific exemplar achieved. An effort to organize one's scientific work is within a certain paradigm. These paradigms (both broad and narrow) stand as a context that, like it or not, influence how scientists doing and deciding their research methods; influence or represent their interests. That's the way science is, it is the being of science.

The empiricist scientist tends to state the objective about nature is scientifically valid as long as it's reflected in human mind (consciousness), a-historical and detached from its paradigm that stands as a context. One of things that is desperately avoided and abhorred by scientists is that science, if contextual, will fall into relativism. This might be the strongest concern that will be questioned to Kuhn regarding his view on science through his view on paradigm: relativism of science. How would Kuhn respond to this? Below is an excerpt from one of the Kuhn's (1970) magnum opus, The Structure of Scientific Revolutions, which would provide a counter argument against the relativist's prejudice:

"Later scientific theories are better than earlier ones for solving puzzles in the often quite different environments to which they are applied. That is not a relativist's position, and it displays the sense in which I am a convinced believer in scientific progress.” (Kuhn, 1970)

Depending on a context, need not be a form of relativism, even that it might have a slight chance of going there, but it's not necessarily fall into it. If you are in a circumstance A, then you should do B, this is not relativism; although not everyone might be in circumstances A.

As mentioned earlier, another key term from Kuhn that will be discussed here is crisis. Crisis, in Kuhn's sense is a special period when existing paradigm has lost the ability to inspire and guide scientists, but when no new paradigm has emerged to get the field back on track (Godfrey-Smith, 2003). It is when scientists start to lose faith in their existing paradigm and this condition is intrigued by an emerging anomaly or a puzzle that has resisted solution. Through this condition of crisis, scientists are challenged to come up or propose a different way of doing science, challenged to propose an inspirational exemplar. In a different way of saying, crisis is condition that makes a paradigm possible. When a different paradigm arises within a particular context, science itself will prevail instead of falling into relativism. Comfort zone, staying tenaciously with disinterested objectivist yet a-historical interpretation in this case, is a sedative drug to established paradigm, to science, and it will faint itself and its method in researching.

Another epistemological concern about traditional science (the objectivist interpretation of the world) comes also from Feyerabend (1993). His notorious view on science is in his famous book Against Method. Here he argued for epistemological anarchism (Godfrey-Smith, 2003). The epistemological anarchist is opposed to all system, rules, and constraints in science.

"Science is an essentially anarchic enterprise: theoretical anarchism is more humanitarian and more likely to encourage progress than its law-and-order alternatives." (Feyerabend, 1993)

From what is stated above, it shows how Feyerabend places a great importance of freedom and creativity of scientist as human individual. Great scientist, in some ways, is opportunistic and creative. Able to initiate him / herself to make use of available technique for the sake of discovery and invention; a great scientist should be able to propose by questioning and criticizing older and existing methods. Any attempt to establish rules or method in science tends to be dogmatic and will stifle the 
aspect of creativity in scientist and science itself. Feyerabend's deepest conviction was that science is an aspect of human creativity (Godfrey-Smith, 2003).

Unlike the objectivists in traditional science who place Cartesian rationality to its highest throne in scientific research, Feyerabend didn't think of that way. To him rationality is merely one of the ways to do a scientific research. Feyerabend relates science more to freedom and human wellbeing. Position rationality as the only way to do scientific research is similar like tying up science in a altar of dogmatizing madness. Science with its rationality is turning scientists into 'human ants' that are entirely unable to think outside of their training (Feyerabend, 1993). And the dominance of science in society dogmatizes each individual into a 'miserable, unfriendly, self-righteous mechanism without charm or humor' (Feyerabend, 1993). If science and rationality become a dogma for society then we, mind as well, are going back to the glorious dark Medieval era. In different way of saying, Feyerabend simply encouraged the aspect of divergent thinking in science and as for the scientists, dare to challenge them to think outside the box or in Kuhn's sense, dare to create a new and different paradigm. In spite of that, this critical view of science from Feyerabend is not free from critics. What is missing in Feyerabend's picture is some rule or mechanism for rejection and elimination of ideas, a lack of converging aspect. But one must admit a great contribution from his view that brings back the aspect of human freedom in scientists. One thing that is quite identical to both thinker as briefly discussed above: science is not about researching through one established method but also proposing a different way of doing it in certain context, certain situation, by position its activity as human centered one. Any a-historical \& a-contextual dogmatic approach of doing science should be questioned and against.

\section{Design and Designers}

Previously we've talked about what is presupposed on traditional scientific research and how is this responded by borrowing two perspectives from two philosophers of science, Kuhn and Feyerabend. Regarding to the title of this paper, Against (design) Research, this section will discuss about what designers do in comparison to the what scientists do traditionally and how is this related to what Kuhn and Feyerabend have proposed for science. The contents of this section are mostly in debt to Klaus Krippendorff (2007), a contemporary design writer and practitioner.

What is design? Going back to its etymology, design comes from the Latin word de and signere. Literally, this means marking out, setting apart, or giving significance by assigning it to a use, user, maker or owner (Krippendorff, 2007). In a different way of putting it, the word 'design' can be read as a sense making activity. The product of design or the design itself are to make sense to their users. Like what is suggested by Feyerabend for science, design is likewise, a human centered activity.

What do designers do in comparison to scientist in traditional sense? Unlike the scientists, designers are not researchers who exclude their interest, context, and subjectivity for the sake of reaching an objective truth. Whereas scientific researchers traditionally privilege causal explanations, that exclude them as initiators or originators of the observed phenomena, designers intend to affect their surroundings by their own actions, their own decisions; and this can not merely be resulted through causal explanations in scientific discourse. Designers always intend to involve their subjectivity and aspect of freedom in their decision making activities. Whereas scientific researchers are concerned only with truth of their propositions, established by claimed-to-be-objective facts or evidence, designers are concerned with the plausibility and compelling-ness of their proposals. Another strong difference between scientists and designers is the way they place rationality. In traditional sense, scientists view rationality as the main way in searching for truth or practically, to achieve scientific and valid solution. Designers view rationality as just one of many ways to solve problems. In fact, rational problem solving (which is positioned on the top of hierarchy in science) is just one of the ways of designing activity itself. Last but not least, scientists tend to research 
disinterestedly in search for truth, while designers, fundamentally, make proposals, embrace their own interest, offer possibilities. The last one is similar to what has been suggested earlier by Feyerabend (1993).

What makes this urges of proposing possible or what motivates designers to propose comes in, as Krippendorff described, three ways. First, along the way, designers will be situated in a troublesome conditions, daunting problems and conflicts. This kind of situation makes challenges possible, challenging the designers to step out form their well-established or comfort zone. Second, these negative harsh conditions allow the designers to see opportunities that might not be seen by others; opportunities to improve other people lives. Third, these opportunities open up possibilities of introducing variations that others might not dare to consider. From what has been described by Krippendorff, we can see how it is well connected to Kuhn's and Feyerabend's critical stance on traditional science. The troublesome situation is crisis in Kuhn's term. Opportunities and offering possibilities of variant are paradigm in Kuhn's sense and also as suggested by Feyerabend regarding to scientific activity. Fundamentally, designers propose proposals and what makes this possible, if for Kuhn it is the crisis, for designers, it is boredom. Boredom for designers is conditions of possibilities to possible possibilities; and by this and only through this, design will prevail existentially.

\section{CONCLUSION}

What is the main critical concern (knowing and spotting similarity between design activity with Kuhn's and Feyerabend's critical suggestion to science) in this article: most designers are and have been doing what Kuhn and Feyerabend suggested critically for science, while science, in certain and particular region or country, is still trying to adapt the traditional way and forcing design approach and activity to go on its way. This is probably quite explicit in applying the word research to design as design research. The objectivist and mechanical interpretation are still trying to be imposed formally by institutions in design; lacking awareness that this can stifle and suffocate the design itself, academically and professionally. Worst case scenario, this will kill design as human centered activity before it grows. Dehumanizing design while claiming design is for human, how ironic. That's why any attempt to impose objectivist interpretation as an absolute necessity towards design should be against, the best we can do is letting design be. Be what? As Feyerabend said: anything goes; embrace it.

\section{REFERENCES}

Feyerabend, P. (1993). Against method (3rd ed.). USA: Verso.

Godfrey-Smith, P. (2003). Theory and reality: An introduction to the philosophy of science. Chicago, USA: The University of Chicago Press.

Hardiman, F. B. (2007). Filsafat fragmentaris, deskripsi, kritik, dan dekonstruksi. Kanisius.

Krippendorff, K. (2007). Design research, an oxymoron? In R. Michel (Ed.), Design research now, essays and selected projects. Germany: Birkhäuser Verlag.

Krippendorff, K. (2006). The semantic turn: A new foundation for design. USA: CRC Press, Taylor \& Francis Group.

Kuhn, T. S. (1970). The structure of scientific revolutions (2nd ed.). Chicago, USA: University of Chicago Press. 